\title{
THE LATE-GLACIAL PERIOD
}

\section{By P. TALLANTIRE and S. M. WALTERS Botany School, Cambridge}

A DISCUSSION on "The Survival and Extinction of Flora and Fauna in Glacial and Post-glacial Times: the Problem Viewed in Relation to Quaternary Historical Investigations" was held by the British Ecological Society at a meeting in the rooms of the Royal Society on October 15, 1946. The president of the Society, Dr. A. S. Watt, pointed out that it was eleven and a half years since the same rooms had witnessed the Royal Society discussion on the "Origin and Relationships of the British Flora". Although there were a number of contributions from pollen analysts in the original discussion, the emphasis had now shifted towards the lines of evidence that they could supply. This meeting was one of a number then being held in connexion with a conference for Quaternary history in north-western Europe.

The first speaker, Prof. K. Jessen, of Copenhagen, said that in previous discussions, as for example at the Royal Society in 1935, all shades of opinion had been represented, from 100 per cent extinction of the British flora and fauna at maximum glaciation, with subsequent immigration, to 100 per cent survival. The real need was for reliable evidence based on actual, macroscopic remains of the plants and animals in question, particularly thermophiles, in glacial and late-glacial deposits. These evidences are few at present, and somewhat idle speculation correspondingly excessive. He gave a résumé, with slide illustrations, of the probable course of the late. glacial vegetational development in north-west Europe, and possibleclimatic inferences. Commencing with his three late-glacial periods: I. Older Salix; II. Allerød ; III. Younger Salix time : distinguishable in Denmark, north-west Germany, and Ireland, he tentatively equated the Younger Salix period with the formation of the Salpausselka moraine stage of the Scandinavian ice-retreat. Subsequent developments were considered to be post-glacial.

A distribution map for period II showed 'tundra' in North Denmark, 'park tundra' to the south, and the northern border of pine and birch forests in South Baltic regions. In Ireland there was 'tundra' over most areas, possibly Empetrum heath in the north and north-west. The forest northern border definitely lay well south of Ireland, but so far its position was unknown for England and Wales. He stressed the difficulties of characterizing the vegetation zones by names, since the conceptions, for example, 'tundra', varied considerably in different regions. 'Park tundra' was intended to connote a tundra vegetation with patches of bare moraine, patches of dwarf salices, Betula nana, Dryas octopetala, etc., and occasional copses of larger birch species in favourable localities. In Zone III certainly no woods were suggested, as evidenced both by the absence of macroscopic remains of tree-birch, there being only one certain locality for this type of birch in Ireland in the Younger Salix period.

Late-glacial sea-levels were known to have been as much as two hundred metres lower than present ones, so that former land-connexions, for example, England to Ireland, Ireland to Spain, and the former southward extension of land in the Solent region in England, may have existed and may possibly have borne forests, for example, of Arbutus, in an oceanic wood flora to the west of Cornwall, as has been suggested (by Du Rietz).

The difference between vegetational development in Ireland and in Denmark was considered due, then as now, to more oceanic climatic influences in the west. The pattern of post-glacial development is parallel in the two countries. In the first post-glacial zone, Zone IV of Jessen, birch (Betula pubescens, agg.) enters in large amount and has an over-all dominance; pine is very insignificant both in the pollen curves and macroscopically. Large willow species are frequent. At the same time, there is an immigration of thermophile aquatic species in both countries, for example, Ceratophyllum demersum. In Zone V, with birch dominance and a spread of hazel, there occurs the first certain evidence for pine, although still in small amounts. In Zone VI $a$, with an astounding hazel preponderance, the two species of Naias appear in Ireland, having been present in Denmark in Zone V as well ; Naias marina represented in a few localities, $N$. flexilis in slightly more. The hazel maximum phenomenon, with traces of mixed oak forest (Quercus + Tilia + Ulmus), is observable all over north-western Europe. Its meaning or contemporaneity are both so far unknown. Uncertain, too, is the pine maximum, in the Boreal Zone VIb in the west of Ireland but delayed until VIc in the north-east.

Since Naias flexilis occurs in Ireland at the present day, its presence in Zone VI may indicate that it is a survival species, at least, that is, indigenous and not re-introduced by human agency. A similar point was made for Eriocaulon septangulare, the pollen of which is found in Zone VII $a$ at Roundstone, a present. day west Ireland locality as well. Three Erica species occur in the Roundstone deposits-the Atlantic species $E$. cinerea from Zones V and VI, $E$. tetralix from Zones V-VIIa, and one of the Lusitanian species, Erica Mackaii, macroscopically identified from leaves, from Zones VI and VIIa and from inter-glacial deposits in the west of Ireland. The present distribution of $E$. Mackaii is Portugal, north Spain, and a few localities in western Ireland apparently as in Boreal times. It is absent from France.

Dr. Jessen concluded by saying that survival and subsequent immigration of species in Denmark was believed to have centred on south-east and south-west Europe. The speed of immigration had been no quicker in Ireland, thus it seemed unlikely that the Irish species survived so close to Ireland as the debatable southern land surface towards the Bay of Biscay.

Dr. J. Iversen, of the Danish Geological Survey, spoke next on some steppe elements in the Danish late-glacial flora and fauna. The first indications of such an element were encountered in the 1800's when Steenstrup described the ground squirrel (Spermophilus rufescens) in a late-glacial freshwater deposit. More recently plant evidence has come to light, and other faunal remains can be roughly dated by pollen analysis methods. Late-glacial finds, in the so-called reindeer period, comprise surprisingly few 'arctic' forms, including only a skull of a mouse hare (Lepus timidus) and a jaw of the glutton. Even these, together with the reindeer, are not solely restricted to an arctic-alpine range but may penetrate the forest belt. Steppe forms have an equal frequency. Time and distribution maps were shown for the bison and wild horse from late-glacial 
and preboreal periods, one find each of the ground. squirrel and mouse have been made from the lateglacial, and four finds of the Irish giant deer dating from the late-glacial and early Allerød. The latter may represent a third, woodland, element restricted to the milder Allerød and post-glacial periods in Denmark. Similarly in north-west Germany, at Ahrendsburg and Meiendorf, bones of the wild horse are reported from the late-glacial stages of the deposits. The plant indices are the high frequencies of Artemisia and Hippophoe pollen from late-glacial maxima of non-tree-pollen. Presence of Hippophoe is proved by finds of the peltate scales. Another index, a species of Helianthemum, now found in Central European mountains but not in Scandinavian mountain regions, is frequent among late-glacial pollen samples. If on retreat of the ice from Denmark the tundra belt disappeared and forests extended practically to the ice margins, then suitable habitats for steppe elements would disappear and no subsequent immigration prove possible, since "the forest is inimical to both arctic and steppe elements". The mixed 'tundra' and 'steppe' flora and fauna probably existed in the belt of 'park tundra', rich in grasses and herbs, of up to a hundred kilometres wide as envisaged by Jessen. This zone and the associated fauna disappeared when post-glacial forest invasion commenced, only the bison and the wild horse lingering until the Maglemosean era in Denmark.

Prof. K. Faegri, of Bergen Museum, dealt with the position of Hippopho rhamnoides in Norway, which in north Europe is restricted to the shores of the Baltic, the north Norwegian and south Danish coasts. Elsewhere in the 'regio alpina media' in Asia, and to sea-level in Scandinavia, it shows a fair degree of tolerance though with some preference for calcareous soil. The fossil distribution appears to have been wide in late-glacial times. A scarcity of localities from Norway is probably due to a scarcity of investigations. Knowledge of ecology suggests that its disappearance is unlikely to have been due to temperature changes. Competition, or the lack of it, or soil leaching are more likely factors, as is indicated by present distribution on regions of coastal uplift, that is, where new ground is continually present and where Hippophoe acts as a pioneer species and so maintains itself. The one or two inland stations recorded are similarly on friable calcareous cliffs where rockfalls keep the habitat open. It may be that until the post-glacial forests closed in there existed habitats of suitable open ground or with minimal competition in the shrub layer.

Dr. F. Mitchell, of Dublin, described discoveries in Ireland of remains of the giant Irish deer and reindeer. Recent work in Ireland on 'zoned' plant beds in relation to glacial deposits has led to a modification of Charlesworth's views of the distribution of the Newer Drift as shown in his map of 1929. This is the separation of the mountain glaciation phase in Ireland, principally of the Wicklow Mountains (and perhaps correspondingly, therefore, in the Welsh Mountains), as of a later date than the Newer Drift. The Scottish Re-advance may well date from this phase as well. In the lowlands solifluxion deposits were formed during the period of Jessen's Zone III. Two distribution maps were shown, one for lateglacial deposits, and localities with finds of giant Irish deer actually found embedded in such deposits, the other constructed for finds recorded in the literature, whether supported by reliable field evidence or not, of reindeer finds from open country sites (finds from limestone caves being neglected). There is a frequent association of reindeer bones with those of the giant deer, for example, at Ballybetagh.

In localities surrounded by steeper and better drained slopes the solifluxion layer may contain such arctic plants as Armeria (?arctica), Dryas octopetala and Oxyria digyna. The distribution of the two large mammals tends to be general except for a lack in the north and north-west. This compares with Jessen's recognition of tundra or open willow and juniper woods over most of Ireland, and Empetrum heaths in the north-west in the Allerød period; the former areas being grassier and thus possibly preferred by reindeer. The Allerød period appears to have been the period when the giant deer flourished; later finds of it are of dubious validity. One from the region to the north of the conjectural ice limit of the Scottish re-advance stage in Ulster, if confirmed, raises the problem of the contemporaneity of the Scottish and Wicklow mountain glaciations and the question of whether the fauna survived, however meagrely, into early post-glacial times. Probably extinction occurred, more or less completely, in the rigorous tundra phase after the Allerød period.

Dr. K. B. Blackburn, King's College, Newcastle, described two anomalous finds, one of Trapa natans in the Scottish Outer Isles, and one of the moose (Alces Alces) in the Tees Valley at Neasham. All they have in common is that both are now extinct in Britain, while both were present together in Cromer Forest Bed times.

The fossil Trapa nut was found entangled in floating Potamogeton debris in a loch in South Uist. The loch is brackish and connects to the sea-loch, Loch Eynort, by a tide-race $10 \mathrm{ft}$. wide and about 50-100 yd. long. The nut was dated by obtaining a pollen sample from adhering peat. 140 tree-pollen grains and some non-tree-pollens were obtained, and the spectrum constructed from them was matched with the longest peat profile diagram so far obtained in the neighbouring regions. The spectrum appeared to agree with a level about mid-Zone VII of the tentative zoning of the diagram. The two profiles, Stoneybridge and Calvay, both have an Alnus rise at the base which might be equated with the Zone VI-Zone VII transition to Atlantic times. The nut is assumed to be indigenous, since Selaginella and Drosera pollen occurred on the nut as in the Zone VII, and other zones of the diagrams, and, it may be added, in the local vegetation at present. No pollens were found on the nut that were not represented from the diagrams, and this also suggested that the nut had not been washed up Loch Eynort into Loch Ceann-a-bhaigh from the sea. A European distribution map for Trapa was shown.

The moose skeleton at Neasham fell out of a peaty band halfway up a brickpit face. This band is inferred to be a deep-water lake-mud. The sequence of deposits was as follows:

3. Clay.

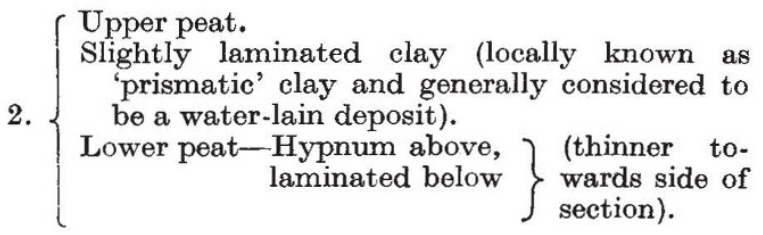

1. Clay. 
In Raistrick's map of the distribution of lateglacial lakes ponded by the Cheviot Ice, one lake is shown over the Neasham district. A pollen diagram was made for the section. The lower peat shows high values for pine basally followed by high birch and willow and a reversion to high pine at the top. There is an increase in the alder curve in the upper peat which may mark the start of Zone VII. The central part, in which the moose was found, may be late-glacial; but the presence of high hazel values at the same level needs accounting for if the clay above is to be suggested as belonging to Zone III, and such correlations are scarcely justified at this stage. The present range of the moose includes the forested lake country of northern Canada.

Prof. Heslop Harrison's paper was read, in his absence, by Prof. Clapham. There are four elements concerned. The 'American' group of species such as Spiranthes stricta, Eriocaulon, Sisyrynchium, Naias flexilis, and the sponge Heteromyelia Rylei. This group is largely centred on the group of islands between the Outer and Inner Hebrides, Coll, Tiree, and Gunna, particularly the first-named. Secondly, the so-called 'Macaronesian' element including the moss Myurium hebridarum, which occurs in the Outer Isles in places, Coll, Tiree, and Eigg, in a non-fruiting state, its principal centre being the Canary Islands and the Azores. Another in this element is the waterbeetle Deronectes canariensis. Thirdly, there is the development of the distinct Hebridean races of plants and animals common on the mainland, for example, wren, thrush and field-mouse and many insects ; such plants as Orchis hebridensis, Lonicera, Pericylmenum var. Clarkii, Rosa spp. The fourth element is that of the arctic alpines.

All the problems have to be reviewed in relation to what is known, as yet, of the geological and geographical history of the whole group of islands during glacial and late-glacial times. There has been too much speculation about these regions up to the present, based on erroneous information or none.

Jehu and Craig considered some time ago the upper slopes, above 1,500 ft., of Bheinn Mohr in South Uist, to be unglaciated. The many changes of sea-level in glacial, late- and post-glacial times presume certain linkages and separations of the various island groups one with another, and with the mainland and Ireland. As regards such islands as Coll and Tiree, a not very extensive rise in former sea-level, for example, to the $100 \mathrm{ft}$. beach-level perhaps, would have been sufficient to submerge them completely, with consequent extinction of the flora and fauna. Similar extinction can be presumed for those islands that were completely glaciated at maximum or subsequent glaciations. Prof. Harrison openly admitted, however, that he has approached the problems with a bias towards a 100 per cent survival of flora and fauna. Pre-glacial raised beaches suggest the Hebrides to have been islands at the start of the Ice Age, presum ably possessing a small flora representative of the rest of the mainland. 'To what extent this was overwhelmed, survived on nunataks, or migrated and afterwards immigrated, depends on glacial conditions at their maximum for each area. On Bheinn Mhor, South Uist, we find such plants as Saxifraga stellaris, Sedum roseum, Oxryia digyna, Alopecurus alpinus (this last nowhere else save on the mainland), Silene acaulis, Carex capitata, C. bicolor, C. glacialis, Poa alpina, Arenaria gothica, Saussurea alpina, and the mosses Andraea vittii, Ditrichum vaginans, and Myurium hebridarum. Can we credit persistence of these plants here, and on mountains of similar heights in this and other islands, on ice-free ledges of high cliffs and nunataks, or possibly on land surfaces exposed by eustatic fall in sea-level ? There is little glacial drift west of the exposed mountains on the Long Island, which may have been ice-free. Among faunal survivals are Bombus spp., Salices, the associated Pontalia and mites, and many spiders.

If the islands were cut off from the mainland after the last inter-glacial by an ice barrier, with no subse. quent land connexion, we might account for the development of the Hebridean races. A previous connexion with the mainland during inter-glacial iso-and eu-static adjustments, allowing immigration to occur in the cases of those islands the floras and faunas of which had been overwhelmed at maximum glaciation previously, could be postulated. All this is hypothetical at the present state of our knowledge. Campylopus Shoreii and Rubus species may have immigrated with the Eu-Hebridean races and survived with them. Where the American element, absent from the Outer Isles, survived is a problem. Possibly on some ice-free area to the west of Ireland; the presence of Eriocaulon in inter-glacial deposits in the west of Ireland may be cited as indicative evidence. Presence before and after a glaciation without knowledge of other factors is not necessarily a priori evidence for survival, however, and the number of investigations of late- or inter-glacial deposits in the Western Isles is very small as yet.

The richness of the flora and fauna of the Inner Isles, in part, compared with that of the Outer Isles, was explained by assuming progressive west to east severance of land connexions. The Coll, Tiree group being cut off later, there was more time available for immigration.

Prof. Zeuner raised the question as to what evidence the geologist can supply towards reconstructing the ecological conditions during late-glacial times. The distribution of fossil soils shows a preponderance of solifluxion phenomena in the west, especially from the south of England and France, but east of the Rhine a dominance of loess types. With solifluxion on a frozen subsoil there may have been taiga conditions such as prevail to-day in Siberia. In the loess areas grass-steppe conditions with an absence of trees, except in the river valley bottoms, where the loess itself appears to be absent, may be conjectured. Between the loess and the Scandinavian ice there was a . 10-100-km. wide belt, presumably of a tundra type, but differing from modern arctic types in its meteorological conditions. The radiation was possibly the same as that to-day for these latitudes, thus a richer flora and fauna may have been possible. The loess conditions disappeared after the Salpausselka stage, climate ameliorated, and the forest belt advanced northwards. Dr. Zeuner is opposed to the survivalists' theory of the Mediterranean and Lusitanian elements in Ireland and Scotland since the existence of the hypothetical land area between Ireland and Spain had never been proved, and he thought that to-day these forms just survived and could not have withstood the rigour of glacial conditions.

Mr. Wilmott assured the meeting that Lusitanian species do not merely just survive in Britain but also flourish from the mountains down to sea-level, although they may be ecotypes of species the southern forms of which could not survive. He cited an instance from a recent cold winter in which Irish forms of Saxifraga umbrosa in his garden survived but the Pyrenean forms were killed. He warned 
foreigners that in Britain they were dealing with the Atlantic climate, which could play many tricks. The Hebrides and Caithness are treeless, but this condition is governed by high winds and lack of snow cover in winter, not of temperature, and there is no tundra there. What degree of coldness did the presence of ice here really indicate ? He pointed out a similarity of British and Finnish floras even to-day.

Mr. C. Elton said that from a zoological point of view the Outer Isles, Shetlands, Isle of Man, etc., appear to have been separated from the rest of Britain since the last inter-glacial, since they lack so many of the species common to the main island. Although the post-glacial vegetational history of Ireland seemed to imply a land connexion in the Holocene, this was inconceivable on zoological and geological grounds. Did man play a more important part than we have imagined up to the present ?

Prof. Jessen, replying to previous speakers, reaffirmed that Ireland in the late-glacial lay to the north of the forest limit. Whether 'tundra', or whatever else it might be called, it was treeless. Arbutus could scarcely have survived on a land surface between Ireland and Spain for, if it did exist, it must have been very oceanic and subject to high winds. Arbutus is a shelter-demanding species. Boreal species might have survived on nunatak areas in the south of England, but doubtfully Lusitanian species. The present distribution of Trapa natans is very sharply defined in the north-west of Europe to-day, in regions of Continental warm summers but immaterial winter conditions. $\mathrm{He}$ doubted if the $18^{\circ} \mathrm{C}$. July isotherm ever existed in the Hebrides region in post-glacial times.

Dr. J. B. Simpson, who surveyed Coll and Tiree for the Geological Survey of Great Britain, was certain that they were completely glaciated at maximum glaciation. Glacial striæ occurred all over these islands at all heights. He wondered if human agency during the Viking period was responsible for any plant introductions. The Outer Isles were regular ports of call for galleys plying between Ireland and Iceland. Further, bird migrants, such as the shearwater, which goes south to the Canaries, might have influenced moss dispersal.

Prof. Faegri was somewhat against a Viking dispersal agency, as many of the species concerned, for example, Arenaria norvegica, Carex bicolor, were extremely rare even in Norway.

Dr. Farrington appealed to botanists to lay aside their speculations and instead seek to establish a reliable geological background for the phenomena of floral history. If the Welsh mountain ice proved to have been pushed about by Northern ice, then it must be earlier than the Wicklow Mountain glaciation. This was considered later than any major ice sheet in Ireland. If varying onsets were established for the different regions, the whole problem of the contemporaneity, at present assumed, was thrown into doubt. If the last glaciation was later than that in Denmark there was no discrepancy in the time for immigration of the floras to be explained. He stressed that the problem of contemporaneity of immigration assumes similar glacial and climatic developments in Ireland and in Denpmark. There are good reasons for thinking that this is far from being the case and that local mountain glaciations occurred later in Ireland. During the Daniglacial and Gotiglacial stages it appears likely that there was a retreating ice margin in Scandinavia, but after the Salpausselka moraine stage the retreat was far more one of the decay of stagnant ice in situ. The Irish conditions are not yet clear. He asked, was the so-called Allerød oscillation contemporaneous or a stage in glacial retreat?

Prof. Flörschutz (Holland) stated that Trapa natans was known from the primary and secondary inter-glacials and from Atlantic times, as a fossil, in Holland.

Dr. E. S. Brown contributed information on insect faunas in the Faroe Islands. In a certain species of Tipulid (cranefly), T. pagana, the females were wingless and therefore could not migrate by flight. Assuming the Faroes to have been islands since lateglacial times, how had this species colonized them ? Bird migration was an unlikely factor since the Tipulid eggs were produced in autumn when the birds were migrating southwards. Human dispersal by boat was also considered unlikely. On many different islands in the group, up to forty miles apart, another species occurred the females of which were practically wingless and in the same position, as regards migration, as $T$. pagana. Transport in hay was later suggested as a factor.

Dr. P. W. Richards suggested that Bryophytes may well prove valuable in the study of these problems. The British flora is particularly rich in relict species, for example, the liverworts, Mastigophora Woodsii and Scapania nimbosa, restricted to the Hebrides, Western Ireland and Western Scotland, and the moss, Myurium hebridarum, are probably pre-glacial relicts. None of these shows spore reproduction in its present station, except Myurium in the Canary Islands, and none has any means of vegetative reproduction. He considered bird dispersal of Bryophytes to be very improbable. Attention was directed to a British-Chinese element represented by Mastigophora with a disjunct distribution in Eastern Asia and the Hebrides. This is comparable to the Chinese-American flora, with only fossil representatives in Europe, for example, Magnolia. He suggested that Bryophyte representatives of these floras, with their small size and great tolerance of unfavourable conditions, might well have survived as relict species to-day. Prof. Jessen's conclusions on the oceanic nature of the late-glacial climate in Ireland were noteworthy. Such species of the arctic-alpine group, for example, Paludella squarrosa, with a relict southern distribution but fairly frequent in the north until drainage operations have caused it lately to diminish, has a very poor representation in Ireland. Could this be due to there never having been suitable conditions there for its establishment after glacial times?

Dr. W. A. Clarke pointed out that the flora of Rhum stands somewhat apart from that of neighbouring islands, possibly due to the higher mountains, reproducing the non-glaciated upper slope conditions of Bhienn Mhor group, South Uist. Such plants as Poa alpina, Saussurea alpina, Thlaspi alpestre, and Arenaria norvegica are present in some quantity at only $1,500 \mathrm{ft}$. The nature of the summits and ridges with angular non-glaciated, but excessively frostshattered, debris recalls Fernald's mountain top survival sites in Newfoundland. The moss Myurium is frequent up to the summit of Bheinn Mhor, South Uist, though the several expeditions to the Clisham area in Harris have not found it there also. He suggested that its lowlands stations were colonized afresh, after survival in the mountain regions, namely, Myurium on Ben na Hoe sea cliff, South Uist, mentioned by Prof. Harrison. 